\title{
STRATEGI IMPRESSION MANAGEMENT PRESIDEN JOKO WIDODO MELALUI KOMUNIKASI PROGRAM PRIORITAS PEMERINTAH DALAM AKUN YOUTUBE "PRESIDEN JOKO WIDODO"
}

\author{
Indira Siedharta $^{1}$, Inri Inggrit Indrayani ${ }^{1}$, Vita Monica ${ }^{1}$ \\ ${ }^{1}$ Program Studi Ilmu Komunikasi, Universitas Kristen Petra Surabaya \\ Email: Indirasiedharta.is@gmail.com, inri.inggrit@petra.ac.id, vita.monica@petra.ac.id
}

\begin{abstract}
ABSTRAK
Impression management adalah suatu proses di mana seorang individu secara sengaja menggunakan komunikasi untuk menciptakan impresi yang diinginkan dari orang lain terhadap dirinya. Setiap individu melakukan impression management, tak terkecuali bagi seorang pemimpin, seperti Presiden Joko Widodo. Dalam penelitian ini, peneliti ingin mengetahui strategi impression management Presiden Joko Widodo melalui komunikasi program prioritas pemerintah dalam akun Youtube-nya, dengan menggunakan metode analisis isi kuantitatif. Peneliti melakukan koding terhadap pesan verbal (pernyataan yang diucapkan oleh Presiden Joko Widodo) yang ada di dalam 169 video sampel. Hasil penelitian ini menunjukkan bahwa strategi yang paling sering ditampilkan oleh Presiden Joko Widodo adalah strategi ingratiation, di mana ia ingin mendapatkan kesan sebagai pemimpin yang disukai. Strategi ini secara dominan ditunjukkan melalui indikator mengucapkan salam, terima kasih, serta menyatakan pernyataan yang bersifat humor.
\end{abstract}

Kata kunci: Strategi Impression Management, Presiden Joko Widodo, Youtube.

\begin{abstract}
Impression management is a process whereby an individual intentionally uses communication to create a desired impression others have about them. Every individual performs impression management, including a leader, such as President Joko Widodo. In this research, the researcher wants to know the impression management strategies of President Joko Widodo through the government priority programs communication in his Youtube account, by using quantitative content analysis method. The researcher did the coding on President Joko Widodo's verbal message (statements that were uttered by President Joko Widodo) in 169 sample videos. The result of this research showed that the most often presented strategy of President Joko Widodo was ingratiation strategy, whereby he wanted to get an impression of likability. This strategy was predominantly demonstrated through indicators of greetings, thanking, and expressing humorous statements.
\end{abstract}

Keywords: Impression Management Strategies, President Joko Widodo, Youtube..

\section{PENDAhUluan}

Menurut Harlow (1976), public relations adalah fungsi manajemen khusus yang membantu menciptakan dan memelihara hubungan komunikasi timbal balik, pemahaman, dan penerimaan, dan kerjasama antara sebuah organisasi dengan publiknya; melibatkan manajemen masalah atau isu; membantu manajemen untuk tetap mendapatkan informasi dan responsif atas opini publik; menentukan dan menekankan tanggung jawab manajemen untuk melayani kepentingan umum; membantu manajemen terus mengikuti dan memanfaatkan perubahan secara efektif, melayani sebagai sistem peringatan dini untuk membantu mengantisipasi kecenderungan (tren); dan menggunakan riset dan suara dan komunikasi etis sebagai tools utama (Strömbäck dan Kiousis, 2011, p.3).

Hubungan antara organisasi dengan publiknya tidak dapat dipisahkan. Publik dapat memiliki pengaruh yang besar terhadap organisasi dan begitu pula sebaliknya, organisasi dapat memiliki pengaruh yang besar terhadap publiknya. Secara konsep, hal ini mirip dengan hubungan antara aktor politik dan institusi, aktor media dan institusi, dengan publiknya. Oleh karena itu, baik komunikasi politik dan public relations adalah mengenai hubungan yang terbentuk melalui komunikasi. Terkait dengan penekanannya pada hubungan, keduanya, baik public relations dan komunikasi politik juga memperhatikan konstruksi reputasi dan dampaknya pada persepsi dan tindakan dari stakeholder (Strömbäck dan Kiousis, 2011, p.4).

Munculnya istilah political public relations kemudian, merujuk kepada penggunaan strategi dan taktik public relations dalam konteks politik atau ditujukan untuk tujuan politik. Lebih lanjut, political public relations didefinisikan sebagai berikut: "Political public relations adalah proses manajemen yang mana sebuah organisasi atau aktor individu untuk tujuan 
politik, melalui komunikasi dan tindakan yang bertujuan, berusaha memberikan pengaruh dan menciptakan, membangun, dan memelihara hubungan yang saling menguntungkan dan reputasi dengan publik utamanya untuk membantu mendukung misinya dan mencapai tujuannya" (Strömbäck dan Kiousis, 2011, p.3). Bagaimana stakeholder memproyeksikan image yang nantinya akan membentuk reputasi sebuah organisasi, bermula dari impression management yang dilakukan oleh organisasi (L'Etang, 2008, p.55).

Impression management adalah dasar yang penting bagi manajemen reputasi public relations (L'Etang, 2008, p.60). Asal usul akademis bidang impression management ini bermula dari karya Erving Goffman, The Presentation of Self in Everyday Life (1959). Teori impression management menyebutkan bahwa dalam interaksi sosial setiap individu berupaya menampilkan gambaran dirinya atau konsep dirinya di depan orang lain. Upaya ini disebut impression management, yaitu individu secara sengaja menggunakan komunikasi untuk menciptakan impresi yang diinginkan dari orang lain terhadapnya (Goffman, 1959, p.4).

Dalam interaksi sosial sehari-hari, secara sadar maupun tidak, setiap individu melakukan impression management. Tak terkecuali bagi seorang pemimpin, termasuk bagi seorang presiden. Sebagai seorang pemimpin politik, Presiden Joko Widodo, Presiden ke-7 Republik Indonesia yang sedang menjabat saat ini juga tentu melakukan impression management pada saat berkomunikasi dengan publiknya, di mana proses manajemen yang dilakukan oleh seorang presiden melalui komunikasinya secara khusus masuk ke dalam ranah presidential public relations. Komunikasi sendiri juga merupakan variabel penting dalam kepemimpinan nasional. Memiliki kemampuan dalam mengolah informasi dan menyampaikan informasi dengan tepat merupakan salah satu kebutuhan pemerintah dalam rangka mensukseskan berbagai program pemerintah (presidenri.go.id, 2016). Oleh karena itu, bagaimana Presiden Joko Widodo mengomunikasikan pesannya kepada publiknya menjadi hal yang penting. Hal ini membuat peneliti tertarik untuk melihat impression management yang dilakukan oleh Presiden Joko Widodo pada saat menyampaikan pesannya kepada publik sebagai orang nomor satu di Indonesia.

Di era digital seperti sekarang, Presiden Joko Widodo tidak hanya hadir langsung menyapa rakyat dengan blusukan, tetapi juga menyapa rakyat melalui media sosial. Sampai saat ini, Presiden Joko Widodo telah memiliki lima kanal media sosial yang dapat dimanfaatkan masyarakat dan yang paling baru adalah akun Youtube Presiden Joko Widodo pada platform media sosial Youtube. Menurut Presiden Joko Widodo, pembuatan akun media sosial seperti ini sangat penting bagi pemerintah untuk menyampaikan informasi dan berkomunikasi dengan masyarakat. "Gunakan cara-cara baru dalam menyampaikan informasi, tinggalkan pola-pola lama," kata Presiden di depan para Humas lembaga dan Kementerian di Istana Negara, tanggal 4 Februari yang lalu. Selain itu, peluncuran berbagai akun jejaring media sosial Presiden Joko Widodo ini juga bertujuan untuk lebih mendekatkan Presiden Joko Widodo dengan rakyat (presidenri.go.id, 2016).

Akun resmi "Presiden Joko Widodo" di situs berbagi video itu pertama dibuat pada Jumat, 6 Mei 2015, namun baru diluncurkan untuk publik di Istana Bogor, Sabtu, 28 Mei 2016 pukul 09.00 dan dapat diakses dengan melalui URL http://youtube.com/ c/jokowi. Sampai hari ini (15/7), jumlah subscribers (pelanggan) akun tersebut telah mencapai 333.672 subscribers dengan 13.080.639 kali penayangan. Seluruh video yang diunggah ke dalam akun resmi itu diproduksi bersama antara Tim Komunikasi Presiden dengan Biro Pers serta Media dan Informasi Sekretariat Presiden (presidenri.go.id, 2016).

Kehadiran media sosial dan inovasi di internet membawa perubahan terhadap praktik-praktik public relations yang selama ini dilakukan (Nasrullah, 2015, p.172). Media sosial saat ini menjadi aset yang berharga bagi praktisi public relations, terutama di Indonesia. Media sosial dapat dikatakan sebagai salah satu media komunikasi terbesar dan paling efektif saat ini di Indonesia. Hampir seluruh kegiatan yang dilakukan dalam dunia pekerjaan, khususnya di bidang komunikasi, memiliki keterkaitan dengan media sosial (www.koran-jakarta.com, 2015 dalam Nasrullah, 2015, p.176).

Secara khusus, apabila dibandingkan dengan platform media sosial yang lain, Youtube memungkinkan setiap orang untuk dapat mengunggah video yang dapat langsung dilihat oleh jutaan orang di seluruh dunia dalam hitungan menit. Berbagai jenis konten video yang dapat disebarkan melalui Youtube membuat berbagi video menjadi salah satu komponen penting dalam individual impression management dan social networking (Lange, 2007, p. 361-380). Dengan media sosial, individu juga memiliki kemampuan untuk membuat gambar dirinya untuk tujuan sosial tanpa dibatasi oleh ruang dan waktu. 
Mereka dapat membuat tampilan profil yang strategis untuk mempengaruhi bagaimana orang lain memandang mereka (Rosenberg, 2011, p. 1-18).

Dalam penelitian ini, peneliti akan melihat videovideo yang diunggah ke dalam akun Youtube Presiden Joko Widodo tersebut mulai dari awal dibuatnya akun sampai pada tanggal 31 Desember 2016, yang bertemakan program pembangunan yang menjadi fokus dan prioritas pemerintah. Berbagai program prioritas pemerintah tersebut hadir sebagai turunan dari "Nawa Cita" atau sembilan agenda prioritas Presiden Joko Widodo. Program ini digagas untuk menunjukkan prioritas jalan perubahan menuju Indonesia yang berdaulat secara politik, serta mandiri dalam bidang ekonomi dan berkepribadian dalam kebudayaan (nasional.kompas.com, 2014). Videovideo yang akan diteliti nantinya akan dikelompokkan dahulu ke dalam kategori-kategori program prioritas pemerintah. Kategori-kategori tersebut adalah Kesejahteraan Rakyat, Kesehatan, Pangan, Reformasi Birokrasi dan Perundangan, Investasi, Maritim, Infrastruktur, Pendidikan, Kebudayaan, dan Olahraga, Desa Hutan dan Lingkungan, Industri dan Energi, Internasional, serta Keberagaman dan Toleransi.

Secara spesifik, orang-orang mencoba menampilkan identitas yang berbeda-beda dari dirinya di dalam situasi yang berbeda-beda pula (Lindwall, 2004, p.24). Oleh karena itu, dalam mengomunikasikan masing-masing kategori program tersebut, Presiden Joko Widodo juga tentu mempresentasikan dirinya dengan strategi yang berbeda-beda pula. Dalam penelitian ini, peneliti akan meneliti bagaimana strategi impression management Presiden Joko Widodo melalui komunikasi program-program prioritasnya tersebut.

Adapun penelitian terdahulu, yaitu "Appearing Competent: A Study of Impression Management in US and European CEO Profiles" yang dilakukan oleh I. Pollach dan E. Kerbler (2011). Penelitian ini dilakukan untuk memahami bagaimana perusahaan menciptakan impresi kompeten dari CEO dalam berbagai konteks kultural, dengan meneliti 200 website korporat masing-masing dari Amerika Utara dan Eropa. Hasil dari penelitian analisis isi kuantitatif ini adalah bahwa impression management lebih umum dalam profil CEO di Amerika Utara yang menampilkan CEO sebagai partisipan aktif dalam kehidupan sosial, politik, dan dalam masyarakat. Sedangkan, profil CEO di Eropa menampilkan CEO hanya sebagai seorang pengusaha. Adapun penelitian lainnya, yaitu "Impression Management \& Public
Diplomacy Presented by The President of The Republic of Indonesia: A Comparative Analysis on The Image Management Strategy of SBY and Jokowi at APEC CEO Summit' dilakukan oleh Inri Inggrit Indrayani (2014). Penelitian ini dilakukan dengan menggunakan metode analisis isi kualitatif, dengan membandingkan pidato dari kedua aktor politik tersebut. Hasilnya, SBY menekankan impression management-nya dengan ingratiation dan self-promotion. Sedangkan, impression management dari Presiden Joko Widodo lebih bersifat percaya diri, terangterangan, dan egalitarian sebagai pemimpin yang otoriter. Impression management dari diplomasi publiknya ini dilakukan dengan lebih agresif, detail, dan informal untuk mendapatkan investasi asing.

Berbeda dengan penelitian sebelumnya, dalam penelitian ini, peneliti ingin melihat strategi impression management yang dilakukan oleh seorang individu, seorang aktor politik, yang dilakukan melalui Youtube, dengan menggunakan metode analisis isi kuantitatif. Aktor politik tersebut adalah Presiden Joko Widodo yang sedang menjabat saat ini, dengan melihat video-video yang diunggah dalam akun Youtube-nya, mengenai program prioritas pemerintah. Pada penelitian ini, peneliti ingin mengetahui bagaimana strategi impression management Presiden Joko Widodo melalui komunikasi program prioritas pemerintah secara verbal, sebagai salah satu elemen impression management.

Bahasa verbal adalah sarana utama untuk menyatakan pikiran, perasaan, dan maksud kita. Bahasa verbal menggunakan kata-kata yang merepresentasikan berbagai aspek realitas individual kita (Mulyana, 2012, p.261). Kriyantono (2014, p.217) juga mengatakan bahwa melalui pesan yang sengaja disampaikan, individu secara aktif menggunakan simbol verbal dan nonverbal untuk mengelola kesan yang dia ingin diterima dan dilihat oleh orang lain. Karena simbol verbal yang lebih mudah dikelola, maka pesan yang sengaja disampaikan ini lebih banyak merujuk pada simbol verbal. Oleh karena itu, peneliti memutuskan untuk memfokuskan penelitian pada aspek verbal secara khusus.

Berdasarkan penjabaran di atas, maka peneliti tertarik untuk meneliti strategi impression management Presiden Joko Widodo melalui komunikasi program prioritas pemerintah dalam akun Youtube "Presiden Joko Widodo" dengan menggunakan metode analisis isi kuantitatif, dengan melakukan koding terhadap strategi impression management Presiden Joko Widodo secara verbal. 


\section{TINJAUAN PUSTAKA}

\subsection{Political Public Relations}

Strömbäck dan Kiousis (2011, p.3) mendefinisikan political public relations sebagai berikut: "Political public relations adalah proses manajemen yang mana sebuah organisasi atau aktor individu untuk tujuan politik, melalui komunikasi dan tindakan yang bertujuan, berusaha memberikan pengaruh dan menciptakan, membangun, dan memelihara hubungan yang saling menguntungkan dan reputasi dengan publik utamanya untuk membantu mendukung misinya dan mencapai tujuannya."

Strömbäck dan Kiousis (2011) dalam bukunya Political Public Relations, juga mengatakan bahwa dalam era digital political public relations, dengan adanya peningkatan penggunaan digital communication tools, public relations kembali kepada "hubungan" yang lebih personal dengan publik utamanya. Hubungan adalah aspek primer dalam baik komunikasi politik maupun public relations, oleh karena itu fokus terhadap hubungan menjadi lebih penting dalam political public relations daripada di dalam public relations secara umum karena dalam komunikasi politik selalu ada pendekatan personal dalam berhubungan dengan publik (Strömbäck dan Kiousis, 2011, p.293).

\subsection{Presidential Public Relations}

Kekuatan presidensial adalah kekuatan untuk mempersuasi (Neustadt, 1990), sama seperti public relations pada dasarnya diarahkan pada persuasi (Miller, 1989). Walaupun wajah dari presidential public relations itu adalah presiden itu sendiri, namun tentu bukan individu presiden itu seorang diri yang mempromosikan kedudukan itu serta misinya. Tentu juga merupakan tindakan dari organisasi yang dimiliki presiden pula yang melakukan hal tersebut. Interaksi antara individu presiden dan institusi tersebut yang penting untuk menjelaskan kinerja dan perilaku individu tersebut (Strömbäck dan Kiousis, 2011, p.95).

Strömbäck dan Kiousis (2010) juga menunjukkan bahwa konferensi pers dan pidato utama berkorelasi positif dengan keseluruhan peringkat persetujuan pekerjaan presiden dan persetujuan publik terhadap penangannannya dalam kebijakan luar negeri. Secara teoritis, pidato presidensial meningkatkan akses publik dalam informasi politik yang cenderung bebas biaya (Zaller, 1992). Karena kepresidenan memiliki sumber daya organisasional dan sarana untuk menjangkau publik dan karena sumber publik dari informasi politik yang paling mudah diakses seringkali adalah dari presiden, oleh karena itu menjadi wajar bila presiden menjadi efektif dalam mengolah opini publik sampai pemerintahan tersebut berakhir (Strömbäck dan Kiousis, 2011, p.107).

\subsection{Strategi Impression Management}

Jones dan Pittman (1982, p.235) mengembangkan taksonomi yang luas yang bertujuan untuk menangkap berbagai jenis perilaku impression management yang telah diidentifikasi oleh peneliti-peneliti terdahulu. Taksonomi menurut Jones dan Pittman ini dianggap yang paling sesuai serta umum digunakan oleh individu. Taksonomi ini juga telah divalidasi secara empiris dalam studi yang dilakukan oleh Bolino dan Turnley (2003, p. 141-160). Kelima strategi tersebut adalah:

1. Ingratiation

Strategi yang dilakukan seseorang untuk memperoleh kesan disukai (likability) dari pihak lain. Dalam penelitian ini, strategi ini diturunkan ke dalam indikator-indikator sebagai berikut:

- Mengucapkan salam

- Menyatakan simpati kepada pihak lain, baik dalam bentuk selamat maupun belasungkawa

- Menyebutkan sifat-sifat positif yang dimiliki

- Menyatakan persetujuan terhadap suatu hal yang dikemukakan pihak lain

- Menyatakan sesuatu yang bersifat humor

- Memuji pihak lain

- Mengucapkan terima kasih kepada pihak lain atas sesuatu yang telah mereka lakukan/ berikan

\section{Intimidation}

Strategi yang dilakukan seseorang untuk memperoleh kesan ditakuti dari pihak lain. Dalam penelitian ini, strategi ini diturunkan ke dalam indikatorindikator sebagai berikut:

- Menyatakan perasaan marah

- Menyatakan kekuasaan sebagai pemimpin

- Memberikan perintah yang mengikat untuk dilakukan kepada pihak lain.

- Menyatakan ancaman yang ditujukan kepada pihak lain

3. Self-promotion

Strategi yang dilakukan seseorang untuk memperoleh kesan kompeten dari pihak lain. Dalam penelitian ini, strategi ini diturunkan ke dalam indikator-indikator sebagai berikut:

- Menyebutkan kemampuan-kemampuan yang dimiliki

- Menyatakan pengalaman masa lalu yang mendukung

- Menyatakan optimisme dalam bekerja

- Menceritakan prestasinya sebagai pemimpin 


\section{Exemplification}

Strategi yang dilakukan seseorang untuk memperoleh kesan berintegritas dan layak secara moral (moral worthiness) dari pihak lain. Dalam penelitian ini, strategi ini diturunkan ke dalam indikator-indikator sebagai berikut:

- Mengajak masyarakat untuk berbuat baik kepada sesama

- Menyatakan tindakan yang dilakukannya adalah untuk kepentingan masyarakat

- Menyatakan kejujurannya dalam bekerja

- Menyatakan kedisiplinannya dalam bekerja

5. Supplication

Strategi yang dilakukan seseorang dengan menyatakan kelemahan diri untuk mendapatkan bantuan dari pihak lain. Dalam penelitian ini, strategi ini diturunkan ke dalam indikator-indikator sebagai berikut:

- Menyatakan kelemahan/ketidakmampuannya untuk bekerja sendiri

- Menyatakan keluhannya dalam bekerja

- Menyatakan permintaan bantuan kepada pihak lain

\section{METODE PENELITIAN}

\subsection{Konseptualisasi Penelitian}

Penelitian ini merupakan jenis penelitian deskriptifkuantitatif dengan menggunakan metode analisis isi. Puspowarsito (2008, p.30) mengatakan bahwa tujuan penelitian deksriptif adalah untuk membuat gambaran secara sistematis, faktual dan akurat mengenai faktafakta dan sifat-sifat suatu objek penelitian tertentu. Sedangkan, metode yang digunakan dalam penelitian ini adalah metode analisis isi kuantitatif. Analisis isi ditujukan untuk mengidentifikasi secara sistematis isi komunikasi yang tampak (manifest), dan dilakukan secara objektif, valid, reliabel, dan dapat direplikasi (Eriyanto, 2011, p.15).

\subsection{Subjek Penelitian}

Populasi dalam penelitian ini adalah semua video Presiden Joko Widodo dalam akun Youtube "Presiden Joko Widodo", yang diunggah mulai dari awal dibuatnya akun ini, yaitu 28 Mei 2016 sampai 31 Desember 2016, yang berjumlah 209 video. Teknik penarikan sampel yang digunakan dalam penelitian ini adalah purposive sampling di mana sampel diambil dengan maksud atau tujuan tertentu karena dianggap bahwa seseorang atau sesuatu tersebut memiliki informasi yang diperlukan bagi penelitian terkait. Sampel yang diambil oleh peneliti adalah video Presiden Joko Widodo dalam akun Youtube "Presiden Joko Widodo", yang diunggah mulai dari awal dibuatnya akun ini, yaitu 28 Mei 2016 sampai 31 Desember 2016, yang memuat pesan verbal Presiden Joko Widodo, tidak bersifat repetitif, dan mengusung tema program prioritas pemerintah. Sehingga, berdasarkan ketentuan-ketentuan tersebut, sampel dari penelitian ini berjumlah 169 video.

\subsection{Unit Analisis}

Unit sampel dalam penelitian ini adalah 169 video yang memenuhi kriteria sampling di atas. Sementara, unit pencatatan yang digunakan adalah unit proposisional. Peneliti menghubungkan dan mempertautkan satu kalimat dan kalimat lain dan menyimpulkan pernyataan (proposisi) yang terbentuk dari rangkaian antarkalimat ini (Eriyanto, 2013, p.80). Dengan demikian, unit pencatatan dalam penelitian ini adalah pesan verbal Presiden Joko Widodo berupa pernyataan-pernyataan yang diucapkannya di dalam video-video tersebut.

\subsection{Teknik Pengumpulan Data}

Metode pengumpulan data yang digunakan dalam penelitian ini adalah dokumentasi. Metode dokumentasi adalah metode yang digunakan untuk menelusuri data historis (Kriyantono, 2009, p.118). Dalam penelitian ini yang disebut dokumentasi berupa transkrip video Presiden Joko Widodo yang menjadi sampel penelitian. Kemudian, video-video tersebut dimasukkan ke dalam lembar koding yang dibuat berdasarkan kategori yang ditetapkan pada tahap pembuatan alat ukur, yaitu kategori indikator strategi impression management.

\subsection{Analisis Data}

Keseluruhan data yang diperoleh dan dikumpulkan dianalisis berdasarkan teori yang terkait, lalu keseluruhan data tersebut dideskripsikan dan diinterpretasikan sehingga menghasilkan suatu pembahasan data yang bersifat deskriptif. Dalam penelitian ini, peneliti menggunakan tabel frekuensi, yang dapat memudahkan peneliti dalam menganalisis data secara statistik.

\subsection{Uji Reliabilitas}

Salah satu formula yang dapat dipakai untuk menghitung derajat reliabilitas dari suatu alat ukur adalah formula Holsti. Formula ini dipilih oleh peneliti karena mudah untuk dilakukan dan memberikan 
standar pengukuran yang jelas. Formula ini pertama kali diperkenalkan oleh Ole R. Holsti (1969). Rumus untuk menghitung reliabilitas adalah sebagai berikut (Holsti, 1969, p.140):

Reliabilitas Antar-Coder $=\frac{2 \mathrm{M}}{\mathrm{N} 1+\mathrm{N} 2}$

Keterangan:

M : Jumlah koding yang sama (disetujui oleh masing-masing coder)

N1: Jumlah koding yang dibuat oleh coder 1

N2: Jumlah koding yang dibuat oleh coder 2

Reliabilitas bergerak antara 0 hingga 1 , di mana 0 berarti tidak ada satu pun yang disetujui oleh para coder dan 1 berarti persetujuan sempurna di antara para coder. Dalam formula Holsti, angka reliabilitas minimum yang ditoleransi adalah 0,7 atau $70 \%$. Artinya, kalau hasil perhitungan menunjukkan angka reliabilitas di atas 0,7 berarti alat ukur ini benar-benar reliabel. Tetapi, jika di bawah angka 0,7 berarti alat ukur (coding sheet) bukan alat yang reliabel. Hakim dalam penelitian ini adalah The Agnes Angelita alumni Program Studi Ilmu Komunikasi angkatan 2012 yang melakukan penelitian analisis isi tentang "Analisis Isi Implementasi Competitive Identity pada Nation Branding "Imagine Your Korea" di Facebook" pada skripsinya. Peneliti akan menjadi coder 1 dan The Agnes Angelita akan menjadi coder 2.

\section{HASIL DAN PEMBAHASAN}

Berikut akan dijabarkan hasil perhitungan strategi impression mangement Presiden Joko Widodo secara keseluruhan:
Secara keseluruhan, hasil pengkodingan dan perhitungan dalam penelitian ini menunjukkan hasil sebagaimana ditampilkan dalam tabel 1 di atas. Dari tabel di atas, tampak bahwa dari 169 video Presiden Joko Widodo, peneliti mendapatkan bahwa strategi impression management ingratiation merupakan strategi yang tampak paling menonjol atau paling sering muncul dibandingan keempat strategi lainnya, ditunjukkannya dengan perolehan jumlah persentase $33,58 \%$. Setelah itu, diikuti dengan strategi exemplification dengan perolehan jumlah persentase $26,10 \%$ dan self-promotion sebanyak $18,61 \%$. Menyusul di bawahnya, terdapat strategi intimidation dengan jumlah persentase 10,95\% dan supplication dengan perolehan jumlah persentase yang tidak terpaut jauh, yaitu $10,77 \%$.

Rosenfeld, Giacalone, dan Riordan (1995) mengatakan bahwa impression management adalah proses di mana seseorang berusaha untuk mempengaruhi image mereka di mata orang lain (Bolino dan Turnley, 1999, p.187). Oleh karena itu, seseorang tersebut memilih strategi yang digunakan tersebut berdasarkan image yang ingin mereka peroleh dari orang lain. Kelima strategi impression management ini tentu melahirkan image yang berbeda-beda dan sebenarnya tidak dapat dipisahkan secara satu per satu, karena pada dasarnya perpaduan di antara beberapa strategi sekaligus merupakan hal yang mungkin. Oleh karena itu, tampak pula bahwa dari hasil penelitian ini, Presiden Joko Widodo, sebagai aktor politik, menggunakan strategi impression management yang berbeda-beda pula untuk sesuai dengan program prioritas pemerintah yang sedang dibahas,

Tabel 1. Strategi Impression Management Presiden Joko Widodo

\begin{tabular}{|c|c|c|c|c|c|c|}
\hline Kategori Program Prioritas Pemerintah & $\mathbf{I}$ & Int & S-P & $\mathbf{E x}$ & Supp & Total \\
\hline Kesejahteraan rakyat & 16 & 11 & 1 & 16 & 8 & 52 \\
\hline Kesehatan & 6 & 0 & 0 & 5 & 0 & 11 \\
\hline Pangan & 9 & 4 & 10 & 8 & 4 & 35 \\
\hline Reformasi Birokrasi dan Perundangan & 19 & 8 & 20 & 20 & 9 & 76 \\
\hline Investasi & 3 & 2 & 4 & 2 & 1 & 12 \\
\hline Maritim & 2 & 2 & 2 & 2 & 0 & 8 \\
\hline Infrastruktur & 11 & 12 & 12 & 35 & 9 & 79 \\
\hline Pendidikan, Kebudayaan, Olahraga & 15 & 2 & 2 & 4 & 3 & 26 \\
\hline Desa, Hutan, dan Lingkungan & 5 & 1 & 4 & 6 & 2 & 18 \\
\hline Industri dan Energi & 18 & 4 & 18 & 20 & 10 & 70 \\
\hline Internasional & 22 & 4 & 15 & 4 & 3 & 48 \\
\hline Keberagaman dan Toleransi & 58 & 10 & 14 & 21 & 10 & 113 \\
\hline Total & $\begin{array}{c}184 \\
33,58 \%\end{array}$ & $\begin{array}{c}60 \\
10,95 \%\end{array}$ & $\begin{array}{c}102 \\
18,61 \%\end{array}$ & $\begin{array}{c}143 \\
26,09 \%\end{array}$ & $\begin{array}{c}59 \\
10,77 \%\end{array}$ & $\begin{array}{c}548 \\
100 \%\end{array}$ \\
\hline
\end{tabular}

Keterangan:

I : Strategi ingratiation

Int : Strategi intimidation

Ex : Strategi exemplification

S-P: Strategi self-promotion

Supp : Strategi supplication 
yang tentunya memiliki tujuan yang berbeda pula dalam setiap kategorinya.

Strategi ingratiation adalah strategi impression management yang dilakukan untuk mendapatkan kesan disukai dari pihak lain (likable) (Jones dan Pittman, 1982 , p. 249). Dalam mengomunikasikan program prioritas pemerintah di dalam akun Youtube-nya, Presiden Joko Widodo tampak menunjukkan strategi ingratiation di mana beliau ingin mendapatkan kesan sebagai pemimpin yang disukai, lebih banyak dibandingkan dengan strategi lainnya. Hal ini tampak dari jumlah koding dalam strategi ingratiation yang menunjukkan angka yang relatif tinggi hampir di semua kategori dan menunjukkan kemunculan secara terus menerus pula dalam semua kategori program prioritas pemerintah. Dalam strategi ini, mengucapkan salam, mengucapkan terima kasih, serta menyatakan sesuatu yang bersifat humor menunjukkan tiga indikator dengan jumlah koding tertinggi.

Menurut Jones dan Pittman (1982, p. 235), tujuan dari para pelaku strategi ingratiation, yaitu meliputi beberapa karakteristik, seperti: dipandang sebagai sosok yang memiliki kehangatan, humor, dapat dipercaya, pesona dan daya tarik fisik. Kehangatan dapat ditunjukkan dengan salah satunya, mengucapkan salam kepada lawan bicara. Demikian pula, Presiden Joko Widodo juga tampak menunjukkan karakteristik tersebut dalam mengomunikasikan program prioritas pemerintah reformasi birokrasi dan perundangan. Tampak dalam kutipan berikut:

Wassalamualaikum warahmatullahi wabarakatuh. Om Shanti Shanti Shanti Om." (Peresmian Pembukaan Bali Democracy Forum ke 9, Badung, 8 Desember 2016)

Pengucapan salam oleh Presiden Joko Widodo kerap kali dilakukan baik di awal maupun di akhir videonya. Tidak hanya salam dalam bahasa Arab yang biasa digunakan oleh umat Muslim saja, beliau juga kerap kali menambahkan dengan salam khas sesuai daerah setempat, bergantung pada daerah mana beliau berada. Seperti dalam kutipan di atas, "Om Shanti Shanti Shanti Om" memang lazimnya digunakan untuk menutup tulisan atau pidato di Bali. Hal ini menunjukkan adanya keinginan beliau untuk menjadi lebih akrab dan dekat dengan masyarakat setempat, sehingga beliau pun memberikan kesan sebagai pribadi yang hangat. Dengan demikian, beliau menunjukkan upayanya untuk mendapatkan kesan sebagai pemimpin yang disukai.

Dalam video-videonya, beliau juga kerap kali mengucapkan ucapan terima kasihnya kepada pihak lain, misalnya kepada masyarakat, dunia usaha, petugas pemerintah, tokoh-tokoh agama, sampai jajaran pemerintahan negara lain. Beliau seringkali mengucapkan terima kasih atas apa yang telah mereka lakukan/berikan, seperti partisipasi dan bantuannya terhadap pihak pemerintah Indonesia. Dalam berbagai kesempatannya berbicara di depan umum, beliau juga seringkali menyatakan sesuatu yang bersifat humor. Baik itu dalam pidatonya, maupun pada saat berkomunikasi dengan publiknya. Beliau sering mengucapkan kalimat-kalimat candaan yang pada akhirnya mengundang tawa publiknya tersebut. Tindakan-tindakan yang hangat, ramah, dan humor inilah yang secara menonjol beliau munculkan dalam video-video Youtube-nya pada saat mengomunikasikan program prioritas pemerintah, sehingga menjadi wajar bahwa strategi ingratiation-lah yang kemudian muncul sebagai strategi impression management yang paling dominan di antara strategi lainnya.

Berbeda dengan strategi intimidation dan supplication, yang merupakan dua kategori dengan perolehan persentase terendah. Jumlah koding kedua strategi ini di dalam semua kategori juga menunjukkan angka yang relatif rendah, bahkan sempat menunjukkan angka yang sangat rendah, seperti 1 atau bahkan 0 (nol). Kedua strategi ini memang tampak jarang dimunculkan oleh beliau, kecuali pada situasi-situasi tertentu. Misalnya, ketika berbicara mengenai kebijakan, beliau tak segan untuk memberikan perintah yang sifatnya menekan atau bahkan memberikan ancaman untuk memberikan hukuman, seperti mengenai pungli. Seperti tampak dalam kutipan berikut:

"Hati-hati. Saya ingatkan lagi. Hati-hati. Saya sudah ngomong seperti ini. Jangan ada yang berani coba-coba. Silakan kalau berani cobacoba." (Video Presiden Joko Widodo Menyerahkan Sertifikat Tanah Program Strategis Tahun 2016, 10 Oktober 2016)

Sedangkan, strategi supplication, beberapa kali tampak pada saat beliau meminta bantuan kepada pihak lain, seperti masyarakat untuk berpartisipasi membantu program kerja pemerintah.

Gestur-gestur yang bersifat mengintimidasi cenderung membuat para pelaku intimidation kurang menarik dan membuat orang-orang semakin terpisah (Jones \& Pittman, 1982, p.240). Oleh karena itu, ketika Presiden Joko Widodo berupaya untuk mendapatkan kesan disukai, tentu strategi intimidation menjadi sangat rendah karena pada dasarnya, strategi ini merupakan kebalikan dari strategi ingratiation, di 
mana sang pelaku intimidation malah menginginkan untuk mendapatkan kesan ditakuti. Dikatakan oleh Jones dan Pittman (1982, p.247) pula bahwa menyatakan ketergantungan seseorang adalah strategi yang penuh risiko dan kemungkinan akan menjadi salah satu pilihan terakhir. Mungkin ada kerugian besar terhadap harga diri seseorang dalam mengakui keadaan tidak berdaya dan ketidakmampuan seseorang. Oleh karena itu, strategi supplication, di mana seseorang menyatakan ketidakberdayaannya, juga menjadi rendah karena karakteristik-karakteristik pekerja keras dan disiplin dari Presiden Joko Widodo tampak lebih tinggi (tampak dalam strategi selfpromotion dan exemplification) dibandingkan karakteristik-karakteristik dalam strategi ini. Tentu menjadi wajar apabila strategi ini muncul sebagai salah satu yang terendah dari yang ingin ditampilkan Presiden Joko Widodo.

Impression management sebagai bagian dari proses manajemen yang dilakukan oleh aktor politik melalui komunikasi dan tindakan yang bertujuan, berusaha untuk mempengaruhi dan menciptakan, membangun serta memelihara hubungan yang saling menguntungkan dan reputasi terhadap publik utamanya. Semua tindakan tersebut adalah untuk mendukung misi dan tercapainya tujuannya (Strömbäck dan Kiousis, 2011, p.8). Oleh karena itu, strategi impression management yang dimunculkan Joko Widodo ini pun tentu telah dipertimbangkan yang sesuai dengan misi dan tujuannya, terutama dalam kaitannya dengan mengomunikasikan program prioritas pemerintah.

Adapun munculnya strategi ingratiation dengan jumlah persentase tertinggi sebenarnya juga didukung dengan adanya realitas gaya kepemimpinan dan gaya komunikasinya yang memang cenderung terbuka, mulai dari saat beliau menjabat sebagai Wali Kota Solo sampai saat ini. Beliau dinilai sebagai pemimpin yang sederhana, ramah, dan dekat dengan rakyat. Khas dengan metode blusukan, sosok Presiden Joko Widodo yang dekat dengan rakyat semakin kuat. Beliau "menghancurkan" kesan pejabat negara yang angkuh, birokratis, dan formal, serta berjarak. Hadirnya dialog dan kedekatan dengan rakyat menunjukkan bahwa Presiden Joko Widodo, yang sebenarnya juga bertindak sebagai aktor utama presidential public relations sangat mementingkan adanya relasi (relationships) dengan publiknya yang terjalin dengan baik.

Adapun fokus dari aktivitas public relations, adalah menjalin relasi (relationships) yang baik dengan publiknya dan Presiden Joko Widodo, yang sebenar- nya juga bertindak sebagai PR Republik Indonesia secara khas menampilkan hal tersebut dalam masa kepemimpinannya, terutama saat mengomunikasikan program prioritas pemerintahnya. Tidak hanya melalui metode blusukan, namun beliau juga melalui penggunaan digital communication tools, seperti media sosial. Hadirnya media sosial menawarkan berbagai inovasi dan perubahan terhadap praktikpraktik PR yang selama ini dilakukan. Termasuk di dalam political public relations. Penggunaan digital communication tools sangat mendukung bagi seorang PR untuk menjangkau publiknya dan hal ini pula yang dimanfaatkan oleh Presiden Joko Widodo dalam masa pemerintahannya untuk berkomunikasi dengan publiknya, yaitu dengan adanya penggunaan media sosial, salah satunya yang terbaru adalah Youtube.

Kehadiran media sosial ini menawarkan praktik komunikasi dalam hal jangkauan khalayak yang dapat mendukung PR. Jangkauan media sosial dan jaringan pengguna yang jauh lebih besar menjadi kunci sukses untuk membangun kesepahaman antara organisasi dan masyarakat (Nasrullah, 2015, p.172). Oleh karena itu, dengan menggunakan media sosial berupa Youtube, Presiden Joko Widodo pun dapat menjangkau khalayak yang lebih luas. Adanya jaringan pengguna yang jauh lebih besar ini mempermudah Presiden Joko Widodo untuk menyampaikan pesan kepada publiknya, yang pada akhirnya dapat meningkatkan kesepahaman (mutual understanding) antara pihak pemerintah dan publik. Sebagai PR dari Republik Indonesia, penting bagi Presiden Joko Widodo untuk menciptakan adanya mutual understanding dengan publiknya mengingat hal itu merupakan salah satu karakteristik utama dari praktik PR. Hal ini diungkapkan oleh The Institute of Public Relations (Hindson, 1965) di mana praktik PR adalah upaya yang disengaja, terencana, dan merupakan usaha berkelanjutan untuk menciptakan dan memelihara adanya kesepahaman (mutual understanding) antara organisasi dengan publiknya.

Adanya kesepahaman antara pihak pemerintah dan publik ini menjadi penting ketika beliau harus mengomunikasikan program prioritas pemerintah karena dalam menjalankan program prioritas pemerintah, tentu seorang Presiden Joko Widodo tidak dapat bekerja sendiri, melainkan perlu adanya dukungan dari pihak publik untuk membantu menyukseskan program prioritas pemerintah ini. Apalagi, untuk program kerja yang lingkupnya sudah mencapai kepentingan umum seluruh masyarakat Indonesia, tentu adanya partisipasi dari masyarakat sendiri sangat dibutuhkan. Komunikasi yang baik ini dapat mendu- 
kung tercapainya tujuan program kerja pemerintah ini dengan adanya pemahaman yang baik yang pada akhirnya dapat melahirkan partisipasi publik (public participation).

Selain membutuhkan dukungan publik, Presiden Joko Widodo juga membutuhkan dukungan dari organisasi pendukungnya pula. Dalam political public relations, jelas bahwa Presiden menjadi salah satu aktor politik yang melakukan tindakan komunikasi. Namun, meskipun wajah dari presidential public relations adalah presiden itu sendiri, namun bukan presiden itu seorang diri yang mempromosikan kedudukan dan misinya tersebut. Tentu juga merupakan tindakan dari organisasi yang dimiliki presiden pula yang melakukan hal tersebut (Strömbäck dan Kiousis, 2011, p.95). Terkait dengan hal tersebut, maka dalam pengelolaan media sosial, akun Youtube Presiden Joko Widodo menjadi salah satu media komunikasi yang digunakan oleh Tim Komunikasi Presiden untuk menyampaikan pesan-pesan kepada publik. Seluruh video yang diunggah ke dalam akun resmi itu diproduksi bersama antara Tim Komunikasi Presiden dengan Biro Pers serta Media dan Informasi Sekretariat Presiden (presidenri.go.id, 2016).

Informasi yang disajikan melalui media sosial pun cenderung memuat informasi yang utuh dan dapat diakses melalui orang pertama, bukan melalui media massa sebagai perantara. Akses langsung ini akhirnya membawa perubahan terhadap pola komunikasi yang selama ini satu arah menjadi lebih berinteraksi (Nasrullah, 2015, p.172). Demikian pula dalam penggunaan media sosial oleh Presiden Joko Widodo, informasi yang disajikan pun, merupakan informasi yang memang diakses melalui orang pertama, yaitu pihak Presiden Joko Widodo sendiri, dan bukan melalui media massa sebagai perantara. Adanya akses melalui orang pertama tersebut pada akhirnya mendukung adanya keterbukaan (transparansi) pihak pemerintah kepada masyarakat. Hal ini ditunjukkan melalui video-video mengenai komunikasi Presiden Joko Widodo dan informasi perkembangan mengenai program kerja yang diunggah ke dalam media sosial ini. Dengan mengusahakan adanya keterbukaan ini, hal ini juga menunjukkan adanya upaya dari pihak Presiden Joko Widodo untuk menumbuhkan kepercayaan (trust) pihak masyarakat kepada pemerintah, dengan berupaya untuk menghadirkan informasi yang terbuka tersebut.

Dalam bukunya, Political Public Relations, Strömbäck dan Kiousis (2011, p. 96) mengemukakan bahwa cara terbaik bagi presiden untuk mengomuni- kasikan pesan mereka, untuk memelihara dan membangun sebuah hubungan dengan target publik utama mereka, masyarakat Amerika, adalah melalui pidato publik. Presiden menyampaikan beberapa macam pidato, tidak hanya semata-mata untuk perihal audiens dan jangkauan, tetapi juga untuk pencapaian tujuan presiden. Demikian pula hal ini masih relevan dengan apa yang terjadi di Indonesia. Pidato presiden masih menjadi salah satu cara terbaik presiden dalam berkomunikasi dengan publik. Tampak dalam apa yang dilakukan oleh Presiden Joko Widodo. Melalui akun Youtube-nya, tampak bahwa sebagian besar cara komunikasi yang digunakan oleh Presiden Joko Widodo berupa pidato dan sebagian lainnya berupa konferensi pers. Melalui pidatonya, Presiden Joko Widodo dapat menyampaikan berbagai hal, termasuk agenda utama dalam masa pemerintahannya kali ini, yaitu program prioritas pemerintah.

Dengan adanya berbagai realita tersebut, hal ini mendukung munculnya strategi ingratiation sebagai strategi yang paling sering ditampilkan oleh Presiden Joko Widodo. Strategi ingratiation, di mana Presiden Joko Widodo berupaya untuk mendapat kesan sebagai pemimpin yang disukai ini dianggap paling sesuai untuk mendukung Presiden Joko Widodo dalam mengomunikasikan program prioritas pemerintahnya.

\section{KESIMPULAN}

Teori impression management mengatakan bahwa dalam interaksi sosial, setiap individu berupaya menampilkan gambaran dirinya di depan orang lain untuk menciptakan impresi yang diinginkan orang lain terhadapnya. Upaya ini pun juga dilakukan oleh Presiden Joko Widodo, Presiden Republik Indonesia dalam mengomunikasikan program prioritas pemerintah dalam masa jabatannya kepada publiknya. Di era digital seperti ini, Presiden Joko Widodo memanfaatkan media sosial sebagai salah satu media komunikasinya, seperti Youtube.

Dari hasil perhitungan yang telah dilakukan peneliti, strategi impression management ingratiation merupakan strategi yang tampak paling menonjol dibandingan keempat strategi lainnya. Dalam strategi ini, mengucapkan salam, mengucapkan terima kasih, serta menyatakan sesuatu yang bersifat humor menunjukkan tiga indikator dengan jumlah koding tertinggi. Tindakan-tindakan yang hangat, ramah, dan humor inilah yang secara menonjol beliau munculkan dalam video-video Youtube-nya pada saat mengomunikasikan program prioritas pemerintah, sehingga menjadi wajar bahwa strategi ingratiation-lah yang 
kemudian muncul sebagai strategi impression management yang paling dominan di antara strategi lainnya.

Adapun saran peneliti untuk penelitian selanjutnya yaitu, penelitian dapat dilakukan dengan pendekatan yang berbeda, seperti dengan pendekatan kualitatif. Dapat pula dilakukan dengan metode yang berbeda, seperti analisis teks. Seiring dengan berkembangnya dunia digital, penelitian ini juga dapat dilakukan pada media yang berbeda pula. Peneliti berharap penelitian ini dapat digunakan oleh tim komunikasi Presiden sebagai masukan terkait strategi impression management Presiden Joko Widodo dalam akun Youtubenya dan dapat memberikan referensi mengenai strategi impression management seorang pemimpin politik, baik bagi yang sedang menjabat saat ini maupun yang akan menjabat di masa yang akan datang.

\section{DAFTAR PUSTAKA}

Bolino, M. C., \& Turnley, W. H. (1999). Measuring impression management in organizations: A scale development based on the Jones and Pittman Taxonomy. Organizational Research Methods, 2(2), 187-206.

Bolino, M. C., \& Turnley, W. H. (2003). More Than one way to make an impression: Exploring profiles of impression management. Journal of Management, 29(2), 141-160.

Eriyanto. (2011). Analisis Isi. Jakarta: Kencana

Goffman, Erving. (1959). The Presentation of Self in Everyday Life. United States: Anchor Books.

Holsti, Ole R. (1969). Content Analysis for the Social Science and Humanities. Massachusetts: Addison-Westley Publishing.

Indrayani, Inggrit. (2016). Impression Management \& Public Diplomacy Presented by The President of The Republic of Indonesia: A Comparative
Analysis on The Image Management Strategy of SBY and Jokowi at APEC CEO Summit. Journal of Government \& Politics, 7(3), 473492.

Jacquie, L'Etang. (2008). Public Relations Concepts, Practice and Critique. UK: SAGE Publications Ltd.

Jones, E. E., \& Pittman, T. S. (1982). Psychological Perspectives on the Self. London: Laurence Erlbaum Association.

Kriyantono, Rachmat. (2014). Teori Public Relations Perspektif Barat \& Lokal. Jakarta: Prenada Media Kencana.

Lange, P. G. (2007). Publicly Private and Privately Public: Social Networking on YouTube. Journal of Computer-Mediated Communication, 13(1), 361-380.

Lindwall, Magnus. (2004). Exercising the Self: On the Role of Exercise, Gender, and Culture in Physical Self-Perceptions. Sweden: Department of Psychology Halmstad University.

Mulyana, Deddy. (2012). Ilmu Komunikasi Suatu Pengantar. Bandung: PT Remaja Rosdakarya.

Nasrullah, Rulli. (2015). Media Sosial Perspektif Komunikasi, Budaya, dan Sosioteknologi. Bandung: Simbiosa Rekatama Media.

Pollach, I., Kerbler, E. (2011). Appearing Competent: A Study of Impression Management in US and European CEO Profiles, Journal of Business Communication, 48(4), 355-372.

Puspowarsito, H. A. H. (2008). Metode Penelitian Organisasi dengan Aplikasi Program SPSS. Bandung: Humaniora.

Rosenberg, J. and Egbert, N. (2011). Online Impression Management: Personality Traits and Concerns for Secondary Goals as Predictors of SelfPresentation Tactics on Facebook. Journal of Computer-Mediated Communication, 17(1), 118.

Strömbäck, Jesper, \& Kiousis, Spiro. (2011). Political Public Relations. New York: Routledge. 